\title{
PEMBERDAYAAN MASYARAKAT MELALUI PENGOLAHAN LIMBAH KARPET DI DESA CIKAOBANDUNG
}

\author{
Chandra Krisna Dirgantara \\ Program Studi Ilmu Pemerintahan, Fakultas Ilmu Sosial dan Ilmu Politik, \\ Universitas Jenderal Achmad Yani
}

\begin{abstract}
Abstrak
Penelitian ini mendeskripsikan pemberdayaan masyarakat melalui pengolahan karpet dalam meningkatkan ekonomi di Desa Cikaobandung. Penelitian menggunakan metode deskriptif kualitatif. Subjek penelitian adalah anggota pengrajin kesetaraan dan mereka yang terlibat dalam kegiatan ini. Hasil penelitian menunjukkan bahwa pemberdayaan masyarakat di Desa Cikaobandung melalui kegiatan pengolahan karpet mengikuti pertemuan pemberdayaan, yaitu menentukan lokasi kawasan, mensosialisasikan kegiatan pemberdayaan masyarakat, proses pemberdayaan masyarakat, dan kemandirian masyarakat. Penentuan daerah untuk menentukan bersama di mana pelaksanaan kegiatan pemberdayaan. Sosialisasi Kegiatan Pemberdayaan untuk merangkul masyarakat. Proses pemberdayaan masyarakat melalui implementasi kegiatan pengolahan karpet dengan memproduksi dan memasarkan kesetaraan demi ekonomi. Pada akhirnya kemandirian masyarakat untuk melakukan kualitas dan kualitas produksi, dan memenangkan jaringan wirausaha. Pendapatan orang yang bergabung meningkat. Sebelumnya mereka tidak berpenghasilan, sekarang mereka bisa mendapatkan penghasilan tetap sebesar Rp. 720.000 per bulan.
\end{abstract}

Kata Kunci: Pemberdayaan, Masyarakat, Limbah, peningkatan, ekonomi

\begin{abstract}
Research supports describing community empowerment through carpet processing in improving the economy in Cikaobandung Village. Research using descriptive methods using qualitative. The research subjects were members of equality craftsmen and those involved in this activity. The results showed that community empowerment in Cikaobandung Village through carpet processing activities was following empowerment meetings, namely determining the location of the area, socializing community empowerment activities, the process of community empowerment, and community independence. Determination of the area to determine together where the implementation of empowerment activities. Socialization of Empowerment Activities to embrace the community. The process of community empowerment through the implementation of carpet processing activities by producing and marketing equality for the sake of the economy. In the end the independence of the community to do the quality and the quality of the production, and win the entrepreneurial network. The income of people who join increases. Previously they did not earn, now they can get a fixed income of Rp. 720,000 per month.
\end{abstract}

Keywords: Empowerment, Community, Waste, Improvement, economy 


\section{PENDAHULUAN}

Pemberdayaan masyarakat di Indonesia menjadi salah satu upaya untuk menanggulangi kemiskinan di Indonesia selain dari upaya penyelenggaraan program bantuan sosial yang digulirkan oleh pemerintah untuk mengentaskan kemiskinan di Indonesia. Pemberdayaan dilakukan dalam upaya untuk meningkatkan kualitas kesejahteraan masyarakat yang meliputi kesejahteraaan keluarga, memandirikan masyarakat miskin, mengangkat harkat dan martabat masyarakat miskin, menjadikan masyarakat sebagai subjek dalam bertindak. Pemberdayaan dapat dikakukan oleh pemerintah maupun masyarakat setempat (Mardikanto \& Soebiato, 2019).

Dalam Inpres Nomor 5 Tahun 1993 yang lebih dikenal dengan Inpres Desa Tertinggal (IDT), mengintruksikan kepada kabinet pemerintahan untuk melaksanakan program peningkatan penanggulangan kemiskinan. Program IDT merupakan bagian dari Gerakan nasional untuk penanggulangan kemiskinan yang dilaksanakan secara bertahap dan berkelanjutan dengan mengikutsertakan berbagai instansi dan lembaga, baik Pemerintah maupun swasta, termasuk perguruan tinggi, dunia usaha, organisasi kemasyarakatan dan lembaga kemasyarakatan lainnya;

Program IDT juga merupakan strategi pelaksanaan penanggulangan kemiskinan yang menyeluruh dan terpadu untuk mempercepat perkembangan sosial dan ekonomi masyarakat/desa tertinggal menuju kondisi ketangguhan, ketahanan dan kemandirian; Program IDT menyediakan bantuan khusus berupa modal kerja bagi kelompok penduduk miskin disertai bimbingan dan pendampingan khusus.

Berdasarkan data dari World Bank, dari sekitar 269 juta penduduk Indonesia, masih ada sekitar 25,95 juta jiwa yang hidup di bawah garis kemiskinan. Garis kemiskinan di Indonesia berada di bawah standar dunia, di mana standar kemiskinan dunia sebesar 2 dollar AS, sedangkan di Indonesia hanya 1 dollar AS. Data peta sebaran kemiskinan di Indonesia yang dirilis oleh BPS menunjukan tiga provinsi di Pulau Jawa memiliki penduduk miskin yang 
lebih banyak dibandingkan provinsi lainnya. Tiga provinsi tersebut yaitu Jawa Timur dengan 4.11 juta jiwa penduduk miskin, Jawa Tengah dengan 3.74 juta jiwa, dan Jawa Barat dengan 3,4 juta jiwa.

Desa Cikaobandung, Kecamatan Jatiluhur, Kabupaten Purwakarta merupakan salah satu wilayah yang terletak di daerah Jatiluhur. Sebanyak 73,8\% dari 3.894 jumlah penduduk di Desa Cikaobandung tidak memiliki penghasilan. Artinya desa ini masuk ke dalam kategori penduduk miskin yang berpendapatan di bawah standar kemiskinan yaitu memiliki pendapatan di bawah 1 dollar AS per hari. Melihat kondisi tersebut, maka perlu diakan pemberdayaan masyarakat di Desa Cikaobandung untuk meningkatkan kualitas kesejahteraan masyarakat.

Di Desa Cikaobandung, pemberdayaan masyarakat dilakukan oleh masyarakat setempat yaitu Pengolah limbah industri dari PT Multi Karpet dan didukung oleh pemerintah setempat mendirikan pelatihan pembuatan keset dari hasil pengolahan limbah karpet. Pelatihan tersebut didirikan sebagai upaya untuk memanfaatkan potensi lokal agar dapat dioptimalkan oleh masyarakat Desa Cikaobandung. Berdasarkan masalah di atas, mendorong penulis untuk melakukan penelitian mengenai pemberdayaan masyarakat melalui pengolahan limbah karpet di Desa Cikaobandung Kecamatan Jatiluhur Kabupaten Purwakarta.

Merujuk pada teori pembedayaan masyarakat, peneliti menggunakan empat tahapan kegiatan pemberdayaan masyarakat yang dikemukan oleh Tim Delivery (2004) (dalam Mardikanto, 2016). Empat tahapan tersebut yaitu:

1. Tahap 1; Seleksi Lokasi/wilayah

2. Tahap 2; Sosialisasi Pemberdayaan Masyarakat

3. Tahap 3; Proses Pemberdayaan masyarakat: Kajian pedesaan partisipatif, Pengembangan kelompok Penyusunan rencana dan pelaksanaan kegiatan, Monitoring dan evaluasi partisipatif

4. Tahap 4; Pemandirian Masyarakat 
Pada tahap 1; seleksi lokasi/wilayah, dilakukan dengan pemilihan kriteria yang sesuai dan telah disepakati oleh Lembaga, pihak-pihak terkait, dan masyarakat. Penetapan kriteria ini penting agar pemilihan lokasi dilakukan dengan baik dan tepat serta tercapai pemberdayaan masyarakat yang diharapkan.

Pada tahap 2; sosialiasi pemberdayaan, proses ini sangat penting untuk menentukan minat atau ketertarikan masyarakat untuk berpartisipasi (berperan dan terlibat) dalam program pemberdayaan masyarakat yang dikomunikasikan.

Pada tahap 3; proses pemberdayaan masyarakat, dilakukan untuk meningkatkan kemampuan dan kemandirian masyarakat dalam meningkatkan taraf hidupnya.

Pada tahap 4; pemandirian masyarakat, dilakukan pendampingan untuk menyiapkan masyarakat agar benar-benar mampu mengelola kegiatannya sendiri. Proses pemberdayaan masyarakat harus didampingi oleh suatu tim falisitator yang bersifat multidisiplin. Tim pendamping ini merupakan salah satu external factor dalam pemberdayaan masyarakat, yang berperan aktif pada saat proses awal namun akan berkurang secara bertahap selama proses berjalan sampai masyarakat sudah mampu melanjutkan kegiatannya secara mandiri.

Melihat permasalahan yang terjadi, diperlukan penelitian lebih lanjut tentang pelaksanaan pelatihan tersebut agar dapat diketahui peranannya dalam peningkatan ekonomi desa. Berdasarkan latar belakang di atas penulis tertarik untuk membahas masalah mengenai pemberdayaan masyarakat melalui pengolahan limbah karpet di Desa Cikaobandung Kecamatan Jatiluhur Kabupaten Purwakarta. Untuk itu penulis mengajukan skripsi dengan judul "Pemberdayaan Masyarakat Melalui Pengolahan Limbah Karpet Di Desa Cikaobandung Kecamatan Jatiluhur Kabupaten Purwakarta". 


\section{METODE PENELITIAN}

Penelitian ini merupakan penelitian deskriptif kualitatif. Menurut (Moleong, 2011) penelitian kualitatif, prosedur analisis tidak dihasilkan dengan memakai prosedur analisis statistic. Penelitian kualitatif didasarkan pada usaha membangun pandangan atas sebuag objek yang diteliti dengan rinci. Pandangan tersebut dibuat dengan kata-kata holistic, dan rumit. Penelitian ini dilakukan di Desa Cikaobandung. Teknik pengumpulan data yang digunakan antara lain, wawancara, observasi, dokumentasi dan studi Pustaka. Adapun informan dalam penelitian ini adalah anggota pengrajin.

\section{HASIL DAN PEMBAHASAN}

\section{Pemberdayaan Masyarakat Melalui Pengolahan Limbah Karpet Menjadi Keset Di Desa Cikaobandung}

Hasil penelitian menunjukan bahwa pemberdayaan masyarakat melalui pengolahan limbah karpet yang dilaksanakan di Desa Cikaobandung merupakan kegiatan yang dilaksanakan untuk tujuan peningkatan kesejahteraan masyarakat dalam meningkatkan perekonomian anggota atau masyarakat Desa Cikaobandung. Kegiatan ini berupa pemberian keterampilan pengolahan limbah karpet menjadi keset yang dapat digunakan untuk bekal bekerja mandiri dalam bidang wirausaha pembuatan keset dari hasil pengolahan limbah karpet.

Kegiatan pengolahan limbah karpet menjadi keset memiliki peran penting dalam proses pemberdayaan masyarakat karena mampu membuat masyarakat berdaya dan memiliki kemampuan untuk memanfaatkan sumber daya lokal yang ada di sekitarnya sehingga dapat bernilai ekonomi. Pelaksanaan kegiatan pengolahan limbah manfaatnya sangat dirasakan oleh masyarakat di Desa Cikaobandung.

Berdasarkan hasil pengamatan yang dilakukan di lapangan, dalam proses pelaksanaan pemberdayaan masyarakat melalui pengolahan limbah 
karpet di Desa Cikaobandung diperlukan tahapan-tahapan untuk mencapai keberhasilan dari pemberdayaan masyarakat. Peneliti menggunakan empat tahapan kegiatan pemberdayaan masyarakat yang dikemukan oleh Tim Delivery (2004) (dalam Mardikanto, 2016). Empat tahapan tersebut yaitu tahap seleksi wilayah, sosialisasi pemberdayaan masyarakat, proses pemberdayaan masyarakat, dan pemandirian masyarakat. Melalui hasil pengamatan, pihak terkait melakukan tahapan kegiatan pemberdayaan masyarakat sesuai dengan teori yang dikemukan oleh Tim Delivery (2004) (dalam Mardikanto, 2016). Berikut tahapan-tahapan yang dilakukan untuk melakukan kegiatan pemberdayaan masyarakat di Desa Cikaobandung:

\section{Penetapan Lokasi dan Penetapan Wilayah Kerja}

Pada tahapan ini dilakukan seleksi wilayah untuk pemilihan lokasi atau tempat kegiatan pemberdayaan masyarakat akan dilaksanakan. Pemilihan lokasi harus ditentukan dan disepakati oleh lembaga, pelaku bisnis, pihak-pihak terkait, dan masyarakat. Pada tahap awal pendirian kegiatan pemberdayaan masyarakat di Desa Cikaobandung, penentuan lokasi ditentukan bersama-sama dengan pihak yang telibat yaitu Kecamatan Jatiluhur, Karang Taruna, pengelola limbah, dan masyarakat setempat.

Desa Cikaobandung disepakati sebagai lokasi kegiatan pemberdayaan masyarakat karena memiliki kriteria yang diperlukan sebagai berikut:

1. Memiliki potensi lokal yang dapat dimanfaatkan

2. Jumlah tingkat pengangguran yang perlu diberdayakan cukup tinggi

3. Lokasi Desa Cikaobandung yang strategis

Untuk mendapatkan kesepakatan bersama mengenai penentuan lokasi, pihak-pihak terkait melakukan musyawarah atau rembug desa yang menghasilkan mufakat atau keputusan bersama. Penentuan lokasi sangat penting diputuskan bersama di awal untuk menghindari gesekan atau konflik kepentingan antar semua pemangku kepentingan dan juga untuk membangun sinergi dan memperoleh dukungan berupa partisipasi dari seluruh pemangku 
kepentingan demi keberhasilan program dan kegiatan pemberdayaan masyarakat yang akan dilaksanakan.

\section{Sosialisasi Kegiatan Pemberdayaan Masyarakat}

Dalam upaya mengkomunikasikan rencana kegiatan pemberdayaan masyarakat yang akan dilakukan di wilayah Desa Cikaobandung perlu diadakan sosialisasi kepada masyarakat. Materi yang disosialisasikan mengenai kegiatan, pihak-pihak yang terkait yang akan terlibat dan berpartisipasi, pembagian peran, pendekatan, strategi, dan langkah-langkah yang akan dilakukan. Sosialisasi yang dilakukan kepada masyarakat diadakan dengan cara melakukan rembug desa atau musyawarah yang diikuti oleh seluruh warga desa.

Seluruh masyarakat Desa Cikaobandung diundang dalam kegiatan Rembug Desa, dan turut hadir pihak yang terkait seperti Camat Jatiluhur, Kepala Seksi pemberdayaan masyarakat Kecamatan Jatiluhur, perwakilan dari pelaku bisnis yaitu PT Multi Karpet, pengelola bisnis, perwakilan Karang Taruna. Rembug Desa langsung dipimpin oleh Camat menyampaikan kepada masyarakat bahwa akan diadakan kegiatan pemberdayaan masyarakat di Desa Cikaobandung dan melakukan penyadaran kepada masyarakat Desa Cikaobandung mengenai kedudukan masyarakat sebagai individu dan anggota masyarakat yang harus berperan aktif dalam bermasyarakat

Dari 40 orang yang ikut hadir pada kegiatan Rembug Desa, sejumlah 30 orang berminat untuk ikut berpartisipasi dalam kegiatan pemberdayaan masyarakat. Pada proses ini, pihak yang terkait dan masyarakat berdiskusi serta bermusyawarah untuk mendapatkan hasil terbaik. Hasil diskusi dari musyawarah ini diantaranya:

1. Berdasarkan identifikasi wilayah, permasalahan, dan peluang-peluang yang ada, maka masyarakat sepakat untuk melakukan pemberdayaan masyarakat melalui pengolahan limbah karpet menjadi keset karena Desa Cikaobandung dekat dengan salah satu pabrik pembuat karpet yaitu PT 
Multi Karpet yang bisa memasok bahan berupa sisa limbah industri yaitu karpet yang bisa dimanfaatkan sebagai bahan baku pembuatan keset.

2. Membentuk struktur kepengurusan.

3. Merencakan kegiatan pelatihan pemberdayaan masyarakat melalui pengolahan limbah karpet menjadi keset.

\section{Proses Pemberdayaan Masyarakat}

Pemberdayaan masyarakat di Desa Cikaobandung dilakukan sebagai upaya untuk meningkatkan kemampuan dan kemandirian masyarakat dalam meningkatkan taraf hidupnya. Pada tahapan ini dilakukan pelaksanaan kegiatan pemberdayaan masyarakat melalui pengolahan limbah karpet menjadi keset. Agar proses pemberdayaan masyarakat berjalan lancar, terlebih dahulu dilakukan pelatihan oleh pengelola kepada anggota pengrajin untuk menambah pengetahuan, keterampilan, dan perubahan sikap juga wawasan. Pelatihan ini membahas seputar tata cara pengolahan limbah karpet dari pra produksi, produksi, dan pasca produksi. Selain itu, anggota dibekali ilmu mengenai bagaimana memasarkan keset sehingga terjual dan menghasilkan uang.

Kegiatan pengolahan limbah karpet menjadi keset sudah dilaksanakan sejak tahun 2018, meskipun masih terbilang baru akan tetapi dampak pemberdayaan masyarakat yaitu meningkatkan ekonomi sudah mulai terasa. Ada sebanyak 17 pengrajin yang mendapatkan upah sebesar Rp720.000,dalam sebulan. Itu artinya dalam satu bulan, 17 pengrajin berhasil memenuhi target memproduksi keset sebanyak 5 lembar. Ada sebanyak 5 pengrajin yang mendapatkan upah sebesar Rp.600.000,-, itu artinya ke 5 pengrajin ini hanya mampu memenuhi target 5 lembar karpet sebanyak 20 hari kerja dari total 24 hari kerja. Dan sisanya sebanyak 8 pengrajin hanya mendapatkan upah sebanyak Rp480.000,- karena mereka hanya mampu memenuhi target selama 16 hari kerja saja. 
Tidak meratanya penghasilan dari setiap pengrajin keset disebabkan oleh beberapa faktor diantaranya :

1. Pengrajin tidak masuk kerja disebabkan oleh izin atau sakit

2. Dalam satu hari kerja, pengrajin hanya mampu memenuhi target $50 \%$

3. Dalam satu hari kerja, pengrajin hanya mampu memenuhi target di bawah $50 \%$

\section{Pemandirian Masyarakat}

Prinsip pemberdayaan masyarakat yang bertujuan untuk memandirikan masyarakat dan meningkatkan taraf hidupnya, maka pemandirian masyarakat dilakukan berupa pendampingan untuk menyiapkan masyarakat agar dapat mengelola sendiri kegiatannya. Dalam pelaksanaan pemberdayaan masyarakat melalui pengolahan limbah karpet di Desa Cikaobandung, hasil produksi dan kualitas hasil serta mutu akan dipantau terus perkembangannya. Pengelola juga akan terus melakukan perkembangan wirausaha agar hasil produksi bisa dipasarkan secara luas.

Pemberdayaan masyarakat melalui pengolahan limbah karpet menjadi keset tentunya membuat masyarakat memiliki keterampilan di bidang pembuatan keset mulai dari memproduksi hingga memasarkan produk. Hasil dari pelaksanaan kegiatan ini akan terus dipantau dan diperbaiki agar hasilnya bisa maksimal dan sesuai dengan yang diharapkan. Dampak dari kegiatan ini terhadap kondisi masyarakat dalam upaya meningkatkan perekenomian yaitu:

1. Melalui kegiatan pemberdayaan masyarakat, masyarakat di Desa Cikaobandung lebih mengerti mengenai SDM dan potensi yang dimiliki oleh Desa Cikaobandung.

2. Masyarakat mendapatkan pengetahun dan keterampilan daur ulang pembuatan keset dari limbah karpet. 
3. Melatih masyarakat untuk berwirausaha mandiri dari modal yang sudah disediakan.

4. Masyarakat bisa membuka peluang usaha dan menciptakan lapangan pekerjaan sendiri.

Dari dampak tersebut, terlihat bahwa masyarakat bisa meningkatkan penghasilan dan merubah pola pikir menjadi seorang wirausaha. Dalam hal ini, akan lebih baik ditingkatkan lagi dalam segi sosialisasi kepada masyarakat mengenai kegiatan pemberdayaan masyarakat, agar lebih banyak masyarakat yang ikut bergabung dan berpartisipasi. Selain itu perlu inovasi baru agar pekerjaan lebih cepat dan efektif dengan pengadaan mesin yang bisa mempercepat proses produksi. Pengelola juga hendaknya bekerjasama dengan pemerintah memberikan pengarahan tentang cara penggunaan alat produksi, dan melengkapi fasilitas, sarana prasarana agar kegiatan ini dapat berjalan lebih baik lagi dan semakin berkembang.

Hendaknya meningkatkan partisipasi aktif dari masyarakat untuk kegiatan pemberdayaan masyarakat karena keaktifan mereka merupakan unsur penting dari pemberdayaan masyarakat. Harus terus dilakukan pemantauan agara masyarakat bisa berdaya dengan menciptakan lapangan usaha yang dapat meningkatkan kemampuan ekonomi dan tujuan dari pemberdayaan masyarakt tercapai.

\section{KESIMPULAN}

Berdasarkan uraian dari hasil dan pembahasan yang telah dilakukan, maka peneliti dapat menarik kesimpulan bahwa pemberdayaan masyarakat melalui pengolahan limbah karpet di Desa Cikaobandung Kecamatan Jatiluhur Kabupaten Purwakarta sudah terlaksana dengan baik dan mampu meningkatkan ekonomi masyarakat Desa Cikaobandung. Pelaksanaan kegiatan pemberdayaan masyarakat ini, melalui empat tahapan.yang 
dikemukan oleh oleh Tim Delivery (2004) (dalam Mardikanto, 2016).

Pada tahapan pertama yaitu proses pemilihan lokasi atau tempat kegiatan pemberdayaan masyarakat akan dilaksanakan, berdasarkan hasil musyawarah dengan pihak-pihak terkait melalui kegiatan rembug desa, disepakati bahwa dari 10 kecamatan yang ada di wilayah Kabupaten Purwakarta, Desa Cikaobandung ditetapkan menjadi lokasi untuk kegiatan pemberdayaan masyarakat. Desa Cikaobandung memiliki potensi lokal yang dapat dimanfaatkan oleh sumber daya manusia atau masyarakat sekitar. Selain letak desanya yang strategis, Desa Cikaobandung memiliki jumlah penduduk dengan tingkat pengangguran yang tinggi dan harus segera diberdayakan.

Pada tahapan kedua, dilakukan sosialisasi kegiatan pemberdayaan masyarakat kepada masyarakat di Desa Cikaobandung melalui kegiatan rembug desa. Pada tahapan ini semua pihak yang berkepentingan ikut terlibat. Di tahapan ini juga disampaikan kepada masyarakat akan pentingnya kesadaran untuk meningkatkan taraf ekonomi dan merubah wawasan serta pola pikir untuk menjadi seorang wirausaha. Dari kegiatan rembug desa ditetapkan bahwa masyarakat di Desa Cikaobandung akan melakukan kegiatan pemberdayaan masyarakat melalui kegiatan pengolahan limbah karpet menjadi keset. Membentuk struktur kepengurusan, dan menyusun rencana dan strategi untuk melakukan kegiatan pelatihan pengolahan limbah karpet menjadi keset di desa Cikaobandung.

Pada tahapan ketiga yaitu pelaksanaan proses pemberdayaan masyarakat melalui pengolahan limbah karpet menjadi keset. Di mana pada tahap ini masyarakat melakukan serangkaian kegiatan pengolahan limbah karpet dengan memproduksi keset melalui teknik daur ulang limbah industri padat berupa bahan karpet. Dalam sehari, 30 pengrajin keset ditargetkan untuk dapat memproduksi sebanyak 5 lembar karpet sehingga mereka bisa mendapatkan upah sebesar Rp30.000,-perhari. Dalam sehari, mereka bisa memproduksi 8 kodi atau 160 lembar. Selain memproduksi, pada tahap ini juga mereka melakukan pemasaran untuk menjual produk. 
Pada tahap keempat, dilakukan proses pemandirian masyarakat dengan melakukan pemantauan kualitas dan mutu hasil produksi, serta perluasan jaringan kewirausahaan. Melalui kegiatan pemberdayaan, masyarakat di Desa Cikaobandung lebih mengerti mengenai SDM dan potensi yang dimiliki oleh Desa Cikaobandung dan memiliki keterampilan baru, dan juga melatih masyarakat untuk berwirausaha mandiri dari modal yang sudah disediakan. Pada proses ini juga terlihat bahwa masyarakat yang bergabung dalam pengolahan limbah karpet menjadi keset bisa meningkatkan penghasilan dan merubah pola pikir mereka untuk menjadi seorang wirausaha.

\section{DAFTAR PUSTAKA}

Abdurachmat, I., \& Maryani , E. (1997). Geografi Ekonomi. Bandung: Pendidikan Geografi FPIPS UPI.

Achyar, M. (1997). Home Industri dan Perbaikan Kehidupan Ekonomi Keluarga. Surabaya:: IAIN Sunan Ampel.

Admin. (2017, January 2). Geografi Teknik. Retrieved from ilmugeografi.com: https://ilmugeografi.com/geografi-teknik/pengolahan-limbah-industri

Alfitri. (2011). Community Development: Teori dan Aplikasi,. Yogyakarta:: Pustaka Pelajar.

Arikunto, S. (1998). Prosedur Penelitian: Suatu Pendekatan Praktek. Jakarta: Renika Cipta.

Arikunto, S. (Jakarta). Prosedur Penelitian Pendekatan Praktis. 1991: Renika Cipta.

Asy"earie, M. (1997). Etos Kerja dan Pemberdayaan Ekonomi Ummat. Yogyakarta: Lesfi.

Hutapea, E. (2019, April 15). Bekasi, Karawang, Purwakarta Wilayah Favorit Industri. Properti, p. 1.

Karmana, O. (2007). Cerdas Belajar Biologi. Bandung: Grafindo Media Pratama.

Kartasasmita, G. (1996). Pemberdayaan Masyarakat. Jakarta: CIDES. 
Mardikanto, T., \& Soebiato, P. (2019). Pemberdayaan Masyarakat Dalam Perspektif Kebijakan Publik . Bandung: Alfabeta .

Moleong J, L. (2011). Metodelogi Penelitian Kualitatif,. Bandung: PT Remaja Rosdakarya.

Moleong, L. J. (2006). Metodologi Penelitian Kualitatif. Bandung: Remaja Rosdakarya.

Mubyarto. (1997). Ekonomi Rakyat, Program IDT, dan Demokrasi Ekonomi Indonesia. Yogyakarta : Aditya Media.

Nasir, M. (1988). Metode Penelitian. Jakarta: Galia Indonesia.

Priyono, O. S. (1996). Pemberdayaan Konsep, Kebijakan dan Implementasinya,. Jakarta: Center For Stratigic and Internatoinal Studies.

Salim, P. S. (n.d.). Kamus Bahasa Indonesia, cet ke-3.

Soehadha, M. (2008). Metodologi Penelitian Sosiologi Agama Kualitatif. Yogyakarta: Bidang Akademik Uin Sunan Kalijaga Yogyakarta.

Sugiyono. (2013). Metode Penelitian Kombinasi (Mixed Methos). Bandung: Alfabeta.

Sugiyono. (2016). Metode Penelitian Kualitatif, Kuantitatif, dan R\&D. Bandung: Alfabet.

Suharto, E. (2014). Membangun Masyarakat Memberdayakan Rakyat. Bandung: Refika Aditama.

Sukirno, S. (2005). Jakarta: Raja. Grafindo Persadav: Mikro Ekonomi Teori Pengantar.

Sumodiningrat, G. (1998). Membangun Perekonomian Rakyat dalam Rangka Keterburukan Ekonomi. Yogyakarta: Pustaka Pelaja.

Suwandi, B. d. (2008). Memahami Penelitian Kualitatif. Jakarta: PT Rineka Cipta.

Winardi. (1992). Aspek-Aspek Manajemen Pemasaran; Produk-Strategi Pemasaran-Strategi Pasar-Deferensiasi Produk-Sistem Informasi Pemasaran. Bandung: Madar Maju.

Zubaedi. (2013). Pengembangan Masyarakat Wacana dan Praktek. Jakarta: Kencana Prenada Media Group. 